\title{
Social Support to Adolescents Living with HI/AIDS: an Integrative Literature Review
}

\begin{abstract}
Bruno Felipe Remigio Dâmaso', Clarissa Mourão Pinho², Juliana da Rocha Cabral², Evelyn Maria Braga Quirino², Maria Sandra Andrade3, Magaly Bushatsky4, Regina Célia de Oliveira ${ }^{5}$, Lygia Maria Pereira da Silva ${ }^{6}$
\end{abstract}

\section{Abstract}

Objective: To identify the scientific evidence of the literature on social support for adolescents with HIVIAIDS.

Methods: An integrative review was carried out in the LILACS, BDENF and MEDLINE/PubMed databases, conducted in January 2017.

Results: 12 articles, published between 2005 and 2015, were selected and analyzed, which pointed to the importance of social support to adolescents living with HIVIAIDS. It's important to highlight the particular importance of support from relatives and non-relatives, especially regarding to health services and non-governmental organizations.

Conclusions: The support offered by both family members and institutions is considered a potentiating factor in physical, social and psychological health, in positive behaviors and in coping with the condition of living with HIV and AIDS.
1 Specialist in Infectology by the Program in Public Health of the Hospital University Oswaldo Cruz, Recife, Pernambuco, Brazil.

2 Doctor student of the Associate Program of Nursing PostGraduation University of Pernambuco/State University of Paraíba, Recife, Pernambuco, Brazil.

3 Doctor in Health Science. Professor of Associate Program of Nursing PostGraduation University of Pernambuco State University of Paraíba, Recife, Pernambuco, Brazil.

4 Doctor in Child and Adolescent Health. Professor of University of Pernambuco, Recife, Pernambuco, Brazil.

5 Doctor in Nursing. Professor of Associate Program of Nursing PostGraduation University of Pernambuco State University of Paraíba, Recife, Pernambuco, Brazil.

6 Doctor in Health Science. Professor of University of Pernambuco, Recife, Pernambuco, Brazil.

Contact information:

Lygia Maria Pereira da Silva.

Address: University of Pernambuco. Rua Arnóbio Marques, $n^{\circ} 310$, Santo Amaro, Recife-PE, Brasil. CEP: 50100-130.

Tel: +55 81 9922-2571

” lygia.silva@upe.br

\section{Keywords}

Acquired Immunodeficiency Syndrome; HIV; Social Support; Adolescent. 


\section{Introduction}

The discovery of acquired immunodeficiency syndrome (AIDS) and its etiological agent, the human immunodeficiency virus (HIV), became an important milestone in the history of global health in the late twentieth century, despite the great advance in scientific knowledge and therapeutic plans. In more than three decades of the HIV epidemic, this aggravating health problem still represents a great impact in public health [1].

Adolescents have a particularly high risk of HIV infection. Currently, the age group of 15 to 25 years accounts for $20 \%$ of new virus infections. In Brazil, the World Health Organization (WHO) estimates that between 2007 and 2016, there were 8,023 cases of adolescents with HIVIAIDS in the age group of 10 to 19 years, which comprises adolescence. The population with highest incidence of the disease is concentrated in countries with ineffective health services, extreme poverty, poor dietary conditions and high rates of violence [2-4].

Living with HIV in adolescence involves delicate dimensions, such as the insecurity of having a chronic, treatable, but still incurable disease. Silence and secrecy, the search for normality, the dilemmas of virus transmission and the daily use of antiretroviral therapy (ART). Therefore, the multidisciplinary health team needs to recognize these aspects and develop health orientations that will result in the adolescents' understanding of their role as an active subject, changing the health-disease process, aiming to transcend physical disease control in search of a satisfactory quality of life $[5,6]$.

Inserted in this context, the social support network is able to provide support to adolescents by providing links that enable dialogues on issues that permeate adolescence. Thus, it is possible to create spaces that allow the sharing of anxieties, doubts and concerns of this phase of life and the condition of living with HIV and AIDS, and from this point on, the construction, exchange and reconstruction of knowledge for the autonomy of the adolescent. In this process, it is important the insertion of friends, family and health and education professionals, constituting networks of attention with a significant potential to positively influence the coping of the disease [7].

In this perspective, the multiprofessional team plays a significant role, highlighting the importance of comprehending that living with HIVIAIDS is a process that involves multiple meanings. Therefore, it is important for the professionals to listen attentively and responsibly, which facilitates the externalization of the emotions that will help to promote the selfcare of adolescents diagnosed with HIV and AIDS. In addition, it is essential to develop strategies that include family members to improve the treatment and minimize the social stigma still present in the disease [8].

In the context of intensive care, health professionals also need to invest in actions that ensure the daily and adequate use of drug therapy in order to reduce viral load and preserve immune function. Thus, it is possible to reduce the morbidity and mortality, the health expenditures for hospitalization and improve the quality of life of adolescents living with HIVIAIDS [9].

Due to the existence of scarce data in the current literature on the social support to adolescents living with HIVIAIDS, it was felt the need to conduct such study. Which intends to contribute in the elaboration of strategies that will help the creation and execution of support networks to these adolescents, being able to offer them support; reducing the consequences of a diagnosis of HIV infection and AIDS.

Therefore, this study had as aim, the identification of the literature on social support to adolescents living with AIDS/HIV's scientific evidence.

\section{Methods}

This is an integrative literature review, which consists in the construction of a broad literature analyses with the objective of contributing to discussions 
about methods and results of research, as well as in the reflection of future studies [10].

In order to reach the proposed objective, the integrative review method was adopted in the following steps: 1) The identification of the guiding question; 2) sample selection: criterial determination for inclusion and exclusion of articles and their selection; 3) Studies categorization; 4) Studies evaluation in a critical way; 5) Discussion and interpretation of results; 6) Presentation of the review and knowledge synthesis [11].

From this, the present study used the following guiding question: what are the scientific evidences from the literature regarding social support offered to adolescents living with HIVIAIDS?

The search for data took place on January 2017, through online access to the Latin American and Caribbean Literature on Health Sciences (LILACS), Brazilian Nursing Database (BDENF) and Public Medline (PubMed) databases. The study used the Health Sciences Descriptors (DeCS): "Apoio Social" AND "Adolescentes" AND "HIV", and on PubMed, the Medical Subject Headings (MESH) "Social support" and "adolescent" and "HIV" were used. The flowchart of the article selection process is shown in the Figure 1.

Were used as inclusion criteria: scientific articles, available electronically in Portuguese, English and Spanish, from 2005 to 2015. Chapters of books, dissertations, theses, reports, news and editorials were excluded.

For the collection of data, a full reading of the articles were performed and the information was extracted after exhaustive reading and re-reading of the publications by three researchers. The methodological characteristics of the studies were analyzed using classification of evidence levels: 1) Meta-analysis of multiple controlled studies; 2) Individual study with experimental design; 3) Study with quasi-experimental design (study without randomization with single group pre and post-test, time series or control case); 4) Study with non-experimental design as descriptive correlational and
Figure 1: Flowchart of the article selection process. Recife-PE, 2017.

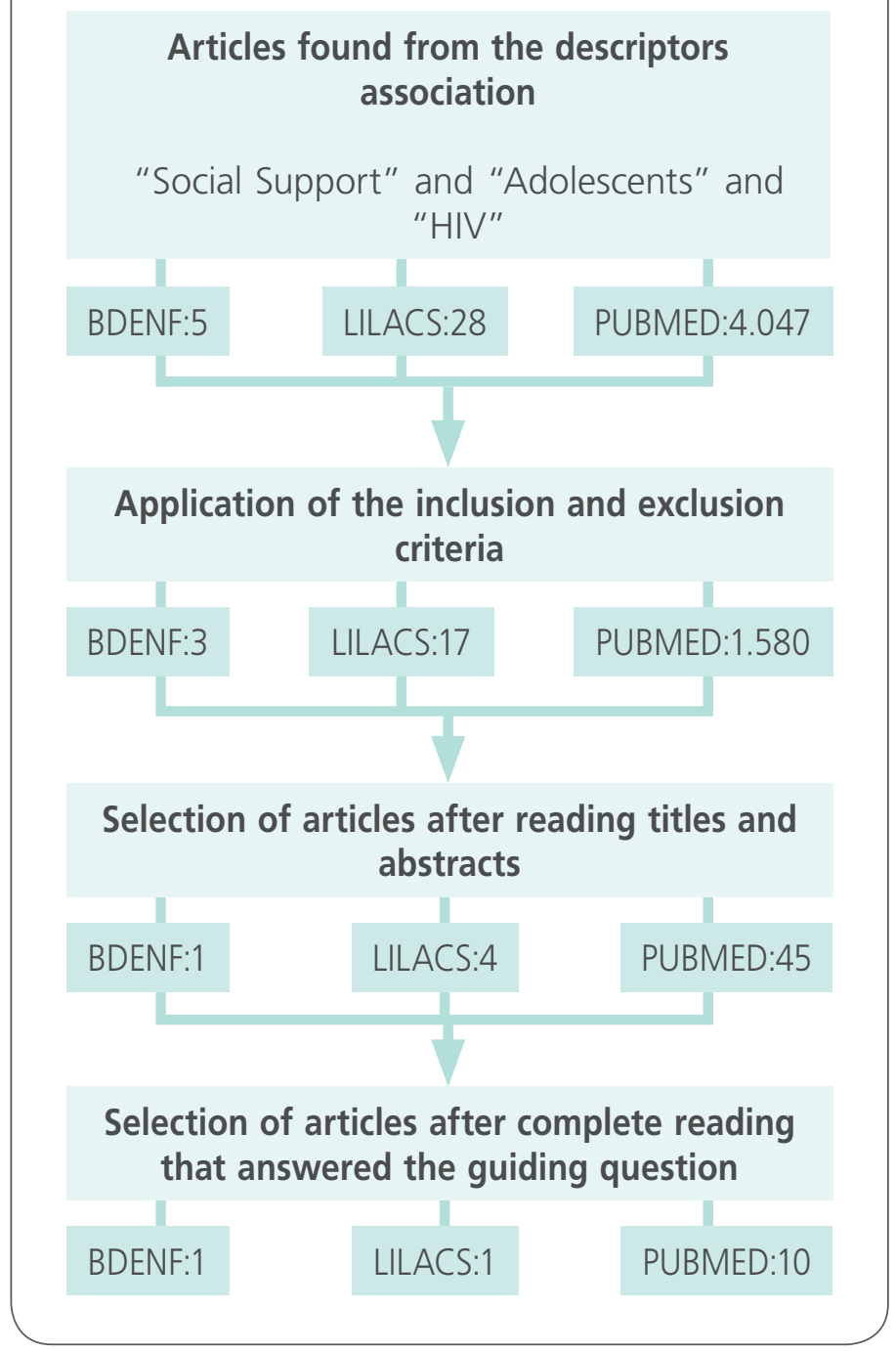

qualitative research or case study; 5) Case report or data obtained systematically, of verifiable quality or program evaluation data $[12,13]$.

\section{Results}

The search carried out in the databases and according to the inclusion and exclusion criteria, were selected 12 articles that are organized in Table 1. The year of publication of articles ranged from 2008 to 2015, five studies were produced by physicians [15, $16,18,19,21]$, three by psychologists along with medical professionals $[20,22,24]$, two by nurses $[14,17]$, one by a public health specialist [25] and 
Table 1. Distribution of the domains and facets of QoL. João Pessoa, PB, 2015.

\begin{tabular}{|c|c|c|c|c|c|c|c|c|c|}
\hline ID* & Authors & Title & Journal & Occupation & Type & Database & Year & Results/Conclusion & Evidence \\
\hline A & $\begin{array}{l}\text { Sehnem } \\
\text { GD, } \\
\text { Favero NB, } \\
\text { Bonadiman } \\
\text { POB }\end{array}$ & $\begin{array}{l}\text { Adolescentes que } \\
\text { vivem com HIV/AIDS: } \\
\text { as redes de apoio } \\
\text { social [14]. }\end{array}$ & $\begin{array}{l}\text { Revista de } \\
\text { Enfermagem } \\
\text { da } \\
\text { Universidade } \\
\text { Federal de } \\
\text { Santa Maria } \\
\text { (UFSM) }\end{array}$ & Nursing & $\begin{array}{l}\text { Descriptive- } \\
\text { exploratory } \\
\text { qualitative } \\
\text { approach }\end{array}$ & BDENF & 2015 & $\begin{array}{l}\text { Eight teenagers that are elementary school students, who lived } \\
\text { with their families, participated in the study. They have reported } \\
\text { that adolescence is a stage of life in which there is no responsibility, } \\
\text { commitments and concerns, moreover, it is a phase of changes } \\
\text { and discoveries. To which regards the social support network, } \\
\text { extrafamilial support is evidenced, in which adolescents report a } \\
\text { stronger trust bond with their friends and companions. Concerning } \\
\text { the HIV status, it was observed that adolescents do not share this } \\
\text { information. Family support was considered impaired. }\end{array}$ & 4 \\
\hline$B$ & $\begin{array}{l}\text { Lowe GA, } \\
\text { Gibson, RC } \\
\text { Christie } \\
\text { CDC }\end{array}$ & $\begin{array}{l}\text { HIV infection, Sexual } \\
\text { Abuse and Social } \\
\text { Support in Jamaican } \\
\text { Adolescents Referred } \\
\text { to a Psychiatric } \\
\text { Service [15]. }\end{array}$ & $\begin{array}{l}\text { West Indian } \\
\text { Med J. }\end{array}$ & Physician & Case series & LILACS & 2008. & $\begin{array}{l}\text { The study was developed with five adolescents assisted at the } \\
\text { University Hospital of the West Indies in Jamaica. It was observed } \\
\text { that adolescents who acquired HIV infection from sexual abuse had } \\
\text { more intense feelings of sadness and suicidal inclination. For those } \\
\text { who had good social support, these feelings were less evident and } \\
\text { they were optimistic about the future. }\end{array}$ & 4 \\
\hline C & Lee $S$, et al. & $\begin{array}{l}\text { Social Support } \\
\text { and Human } \\
\text { Immunodeficiency } \\
\text { Virus-Status } \\
\text { Disclosure to } \\
\text { Friends and Family: } \\
\text { Implications } \\
\text { for Human. } \\
\text { Immunodeficiency } \\
\text { Virus-Positive Youth } \\
\text { [16]. }\end{array}$ & $\begin{array}{l}\text { Adolescent } \\
\text { Health }\end{array}$ & Physician & $\begin{array}{l}\text { Descriptive } \\
\text { exploratory }\end{array}$ & Pubmed & 2015 & $\begin{array}{l}\text { In separate analyzes, younglings (12-24) HIV+ who reported more } \\
\text { than one close friend and young HIV+ who reported that friends } \\
\text { and family members continued to socialize with them after the } \\
\text { diagnostic disclosure had high levels of perceived social support. } \\
\text { Perceived social support did not differ significantly between those } \\
\text { participants in whom no family member knew their HIV status and } \\
\text { those in which at least one family member knew their status. Race, } \\
\text { sexual orientation, education level and current life situation were } \\
\text { not associated with the knowledge of the family regarding the HIV+ } \\
\text { status of the participants. The study concludes that early diagnostic } \\
\text { disclosure may influence resilience and coping mechanisms over } \\
\text { the stigma experienced. Interventions and support systems to help } \\
\text { people living with HIV or diagnosing them can improve overall } \\
\text { quality of life. }\end{array}$ & 4 \\
\hline
\end{tabular}




\section{ID* Authors}

D Peu MD.

\section{Title}

Health promotion strategies for families with adolescents

and AIDS [17]. orphaned by HIV

\section{Journal}

Nursing

Review
Qiao S, Li Social Support

$\mathrm{X}$, Stanton and HIV-related

B.

Risk Behaviors: A

Systematic Review of

[18]. the Global Literature

\section{AIDS Physician Literature Pubmed review}

\section{Results/Conclusion}

Study conducted with professionals dealing with HIV+ adolescents. Four categories of analysis were listed: door-to-door data collection (involving needs assessment, provision of social services and adolescent monitoring programs), results of working groups (determining the value of on-the-job training and community awareness campaigns), the monitoring of statistical data (to evidence progress of social projects and programs) and community projects (integration into social and work projects, with mutual support). The systematization of the evaluation of successful programs can identify the strengths and opportunities of improvement, contributing with the improvement of the quality of the work done in the communities. The results of these assessments can raise awareness among the community, support families and provide statistical data on the impact of HIV / AIDS on families.

The study revealed a complex relationship between social support and HIV-related risk behaviors in all diverse populations studied. The results indicate that higher levels of social support are related to lower levels of risky behavior among HIV/AIDS workers and heterosexual adults in general. However, the influences of social support on risky behaviors related to drug users, men who have sex with men and adolescents were inconsistent. These variations can be attributed to the different measures used to quantify or qualify social support, the contexts of social support and the multiple characteristics of the social networks of the populations studied. It is necessary to focus on the positive effects of social support for all the vulnerable and at risk populations.

\begin{tabular}{|c|c|c|c|c|c|}
\hline $\begin{array}{l}\text { F Mavhu W, } \\
\text { et al. }\end{array}$ & $\begin{array}{l}\text { Enhancing } \\
\text { Psychosocial Support } \\
\text { for HIV Positive } \\
\text { Adolescents in } \\
\text { Harare, Zimbabwe } \\
\text { [19]. }\end{array}$ & Plos one & Physician & $\begin{array}{l}\text { Descriptive } \\
\text { exploratory }\end{array}$ & Pubmed \\
\hline
\end{tabular}

It was observed that $63 \%$ of the participants were at risk of end up with depression. $40 \%$ reported having suffered stigma, from teachers or caregivers, because they are HIV positive and that these professionals reported that there were a possibility of HIV transmission through contact with other children, which shows the lack of preparation of these professionals. Regarding the support group, $91 \%$ of the participants consider it useful to be a member of the group because it makes possible for them to share experiences with other HIV positive younglings.

\section{Evidence}




\begin{tabular}{|c|c|c|c|c|c|c|c|c|c|}
\hline ID* & Authors & Title & Journal & Occupation & Type & Database & Year & Results/Conclusion & Evidence \\
\hline $\mathrm{G}$ & $\begin{array}{l}\text { Salama C, } \\
\text { et al. }\end{array}$ & $\begin{array}{l}\text { Depressive and } \\
\text { conduct disorder } \\
\text { symptoms in youth } \\
\text { living with HIV: } \\
\text { The independent } \\
\text { and interactive } \\
\text { roles of coping and } \\
\text { neuropsychological } \\
\text { functioning [20]. }\end{array}$ & AIDS care & $\begin{array}{l}\text { Psychology/ } \\
\text { Physician }\end{array}$ & $\begin{array}{l}\text { Descriptive } \\
\text { exploratory }\end{array}$ & Pubmed & 2013 & $\begin{array}{l}\text { In a sample of young HIV+ (14-23 years), the combination of } \\
\text { poor neuropsychological activity and negative coping skills were } \\
\text { predictors of depressive symptoms. Neuropsychological activity } \\
\text { and negative coping skills were also associated with symptoms } \\
\text { of conduct disorders. The results highlight the importance } \\
\text { of including neuropsychological assessment in young HIV+ } \\
\text { assessment, particularly those with emotional and behavioral } \\
\text { problems. }\end{array}$ & 4 \\
\hline $\mathrm{H}$ & $\begin{array}{l}\text { Tucker J, } \\
\text { et al. }\end{array}$ & $\begin{array}{l}\text { Social network } \\
\text { and individual } \\
\text { correlates of sexual } \\
\text { risk behavior among } \\
\text { homeless Young } \\
\text { men who have sex } \\
\text { with men [21]. }\end{array}$ & $\begin{array}{l}\text { Elsevier - } \\
\text { Jornal of } \\
\text { adolescent } \\
\text { health }\end{array}$ & Physician & Longitudinal & Pubmed & 2012 & $\begin{array}{l}\text { Study conducted with young homeless men (16-24 years), who have } \\
\text { sex with men. The results show that strengthening social bonds, } \\
\text { such as attending school regularly and not making heavy use of } \\
\text { alcohol can reduce risky sexual behavior. Individual predictors of } \\
\text { risky sexual behavior included older age, Hispanic ethnicity, poor } \\
\text { education, depressive symptoms, less positive attitudes related to } \\
\text { condom use, and sleep. HIV prevention programs for homeless } \\
\text { MSM might ensure a multiple approach that helps these young } \\
\text { people strengthen their social ties, develop more positive attitudes } \\
\text { towards condom use and access health and housing services. }\end{array}$ & 3 \\
\hline I & $\begin{array}{l}\text { Hosek S, } \\
\text { et al. }\end{array}$ & $\begin{array}{l}\text { Evaluating the } \\
\text { Acceptability } \\
\text { and Feasibility of } \\
\text { Project ACCEPT: } \\
\text { An Intervention } \\
\text { for Youth Newly } \\
\text { Diagnosed with HIV } \\
\text { [22]. }\end{array}$ & $\begin{array}{l}\text { AIDS } \\
\text { Education } \\
\text { and } \\
\text { Prevention }\end{array}$ & $\begin{array}{l}\text { Psychology/ } \\
\text { Physician }\end{array}$ & $\begin{array}{l}\text { Descriptive } \\
\text { exploratory }\end{array}$ & Pubmed & 2011 & $\begin{array}{l}\text { The ACCEPT project is a behavioral intervention program for } \\
\text { young people (16-24 years old) diagnosed with HIV. Focused } \\
\text { on combinations of individual and group sessions that allows a } \\
\text { more intensive individual attention as well as support groups. } \\
\text { The project's acceptability and feasibility data demonstrated high } \\
\text { participation rates and high levels of satisfaction regarding the } \\
\text { intervention program, for both participants and program staff. } \\
\text { Data from the exploratory results demonstrated increased levels of } \\
\text { HIV knowledge which were maintained over time and increased } \\
\text { peer support and formal social support right after the intervention. } \\
\text { Gender differences have emerged over time in areas of depressive } \\
\text { symptoms, social support from the family, self-efficacy for sexual } \\
\text { discussion, and personalized stigma. The ACCEPT Project appears } \\
\text { to be a feasible and acceptable intervention to be implemented in } \\
\text { clinical settings for young newly diagnosed HIV+ patients. }\end{array}$ & 4 \\
\hline
\end{tabular}




\begin{tabular}{|c|c|c|c|c|c|c|c|c|c|}
\hline ID* & Authors & Title & Journal & Occupation & Type & Database & Year & Results/Conclusion & Evidence \\
\hline J & $\begin{array}{l}\text { Risio M, et } \\
\text { al. }\end{array}$ & $\begin{array}{l}\text { "HIV isn't me... } \\
\text { ": HIV adolescents' } \\
\text { experiences in a } \\
\text { positive context } \\
\text { of support and } \\
\text { treatment [23]. }\end{array}$ & AIDS Care & $\begin{array}{l}\text { Pharmaco- } \\
\text { logy / Socio- } \\
\text { logy }\end{array}$ & Qualitative & Pubmed & 2011 & $\begin{array}{l}\text { The study showed that HIV+ adolescents had access } \\
\text { to social support in public health programs, focused } \\
\text { on their cases. The presence of adolescents in the } \\
\text { same conditions helps the permanence and interaction } \\
\text { in support groups. In addition to having the social } \\
\text { support coming from model figures, as was the case } \\
\text { of parents also HIV+. Some adolescents report having } \\
\text { greater knowledge about HIVIAIDS, which facilitates the } \\
\text { relationship with less knowledgeable schoolmates. The } \\
\text { major challenges encountered by these adolescents were } \\
\text { to tell their potential sexual partners their serological } \\
\text { status. When asked how they see themselves in the } \\
\text { future, all participants reported that they plan to finish } \\
\text { their education, develop careers, marry, and raise children. } \\
\text { Which evidences a positive attitude in the coexistence } \\
\text { with the disease emerging in the context of the successful } \\
\text { management and support of healthy organisms. }\end{array}$ & 4 \\
\hline K & $\begin{array}{l}\text { Doku P, } \\
\text { Dotse J, } \\
\text { Mensah K, } \\
\text { et al. }\end{array}$ & $\begin{array}{l}\text { Perceived social } \\
\text { support disparities } \\
\text { among children } \\
\text { affected by HIVIAIDS } \\
\text { in Ghana: a cross- } \\
\text { sectional survey [24]. }\end{array}$ & $\begin{array}{l}\text { BMC Public } \\
\text { Health }\end{array}$ & $\begin{array}{l}\text { Cross- } \\
\text { sectional }\end{array}$ & $\begin{array}{l}\text { Psychology/ } \\
\text { Physician }\end{array}$ & Pubmed & 2011 & $\begin{array}{l}\text { A study conducted with children (10-18 years) living } \\
\text { with HIV / AIDS reports different levels of social support } \\
\text { received. The lowest levels of social support were received } \\
\text { by children living with caregivers when compared to } \\
\text { children orphaned by AIDS (parents), children orphaned } \\
\text { by other causes, and non-orphaned children regardless } \\
\text { of sociodemographic levels. Orphaned children who lost } \\
\text { their parents to other causes and orphaned children in } \\
\text { general had similar levels of social support. All the children } \\
\text { in the study received more support from friends and others } \\
\text { than from the family. This indicates the need to develop } \\
\text { interventions that can increase the level of social support in } \\
\text { the context of children living with HIV / AIDS, particularly in } \\
\text { the family context. }\end{array}$ & 3 \\
\hline
\end{tabular}




\begin{tabular}{|c|c|c|c|c|c|c|c|c|c|}
\hline ID* & Authors & Title & Journal & Occupation & Type & $\begin{array}{l}\text { Data- } \\
\text { base }\end{array}$ & Year & Results/Conclusion & Evidence \\
\hline L & $\begin{array}{l}\text { Camlin } \\
\text { C, Snow } \\
\text { R, et al. }\end{array}$ & $\begin{array}{l}\text { Parental } \\
\text { Investment, } \\
\text { Club mem- } \\
\text { bership, } \\
\text { and youth } \\
\text { sexual risk } \\
\text { behavior } \\
\text { in cape } \\
\text { town[25] }\end{array}$ & $\begin{array}{l}\text { Health } \\
\text { Education } \\
\text { \& Behavior. }\end{array}$ & $\begin{array}{l}\text { Public } \\
\text { Health }\end{array}$ & Longitudinal & $\begin{array}{l}\text { Pub- } \\
\text { med }\end{array}$ & 2008 & $\begin{array}{l}\text { The study examines } \\
\text { whether the } \\
\text { investment of parents } \\
\text { and the participation } \\
\text { of adolescents in social } \\
\text { clubs are associated to } \\
\text { safer sexual behavior. } \\
\text { The participation of } \\
\text { clubs (social networks) } \\
\text { and community groups } \\
\text { is related to safer } \\
\text { behaviors. Parents' } \\
\text { financial support is } \\
\text { associated to condom } \\
\text { use, particularly } \\
\text { among young } \\
\text { women, suggesting } \\
\text { that material need } \\
\text { (such as clothing, } \\
\text { school, uniforms, and } \\
\text { allowance) contributes } \\
\text { to vulnerability and } \\
\text { higher risky behaviors. }\end{array}$ & 3 \\
\hline
\end{tabular}

one by a pharmacist and a sociologist [23]. Regarding the language, only one study was published in Portuguese, whilst the others were published in English. The level of evidence ranged from 3 to 5, having eight studies with evidence 4 , three studies with evidence 3 and only one study with a level of evidence 5 .

For better presentation and systematization, the results were categorized into two dimensions: the family dimension and the extrafamilial dimension.

\section{Family Dimension}

The family dimension comprises the first contact with the social network of individuals, it is their own family and constitutes as a valuable resource of social support. A study carried out in Canada with adolescents who were part of a social support group showed that they had positive behaviors as they received support from their parents and guardians, who may or may not be HIV+ [16]. Such study reinforces the fact that the family is a link of great importance for everyone and that can supply the need to seek extrafamilial social support.

Probably influenced by economic and social factors, these findings were inversely related to those found in African countries, which warned that the family and caregivers did not have adequate knowledge to provide support and care for adolescents, as happened in a study developed in Zimbabwe [19]. A study conducted in Ghana presented similar data, since friends offered more support and care than the relatives themselves and caregivers [24], which was reinforced in a South African study [25].

This scenario emerges as a worrisome factor, since adolescence is a phase of the individual's life that comprises several factors predisposing to depression and neuropsychological impoverishment, as demonstrated in a study developed in the United States of America (USA) that correlated the lack of social support and depressive symptoms as the possibility of aggravation of the state of adolescents' health [20]. 


\section{Extrafamilial Dimension}

The extrafamilial dimension is any support network offered by friends, health services and non-governmental community services with the main goal of providing social support and education to its target audience.

Because it is a stigmatizing disease that generates prejudice, adolescents face many obstacles to ensure their physical and mental health. Many organizations have social support as a source of physical and psychological well-being for young people and offer some kind of service for the purpose of cooperation and inclusion among them. These support group activities performed among individuals of the same age group with the multidisciplinary team provide individual and group therapeutic support with the possibility of glimpsing behavior changes [22, 25-27].

In a study conducted in Los Angeles, USA, it was observed that male adolescents, who were homeless and had sex with other men, but who took part in social networks, including schools, and were not heavy drinkers, had a lower frequency of involvement in unprotected sex and fewer sexual partners. Such a finding may have occurred because of the presence of a social bond with a schoolmate in comparison to those who had no affective or social bond at all [21].

These social support centers often seek to develop the adolescent and their self-esteem and thereby achieve independence, improve education, the knowledge about HIV and AIDS. Study developed in South Africa pointed out that support programs directly influenced education, establishment of social support network and expansion of emotional repertoire from four months after the integration of adolescents in these organizations $[22,27]$.

Improving coping skills, developing psychosocial skills, and increasing informational resources contributes to the modification of norms, the promotion of positive attitudes and behaviors [22, 25-27]. Adolescents, in the selected studies, have pointed out that the activities carried out at the support centers are relevant and contribute to significant changes in their lives [18, 19, 22, 25-27].

\section{Discussion}

The social support starts from the first moments of the life of an individual, throughout his/her natural collaborators (family), with the dimensions of affective and material care. These families go through equally troubled phases in the period in which the psychological, social and biological transitions of the adolescents occur. Therefore, in order to approach young people in this period of their lives, it is necessary to take into account the environment and the family's intrinsic development [28].

This oscillation of the family environment is natural for the development of the adolescent, since he goes through stages in his personal and identity constructions. Because of this process of personal identification, there is the conflict between being dependent and being independent. Such scenario justifies the teenager's natural search for friends or social groups to solve problems [29].

This search of the adolescent for the external, in particular, to solve problems inherent or not to adolescence, explains why they seek out institutes and social groups in the search of support. This aspect is observed when analyzing adolescents living with HIV and AIDS, a fact also verified in the present research.

Even if these individuals seek out groups of friends as environments for new experiences and self-knowledge, young people do not seek them out to unburden or confess about diseases that are stigmatized and prejudiced. This is due to the process of belonging to a particular group and in detriment of parental structures [29]. Once out of the "standard" proposed by the group, it would bring a certain disdain on this same group. Because of this, often, they do not seek the help of friends common to their social circles, looking for full support regarding this problem only in health professionals, 
social workers or friends made in support groups of people living with the same problem [23].

In this way, affective support presents a defining and essential character for the nourishment of the being. It is capable of generating security and protection $[28,29]$. Social support has the role of strengthening things, such as the immune system. Greifinger et al (2011) timidly presented this finding in their studies [26], in which the researchers found a slight increase in the CD4 T cell count. In Salama et al (2013) [20], researchers investigating the impacts of lack of social support found a decrease in CD4 T cells, in addition to pointing to predisposing symptoms of depression and psychological disorders. Hosek et al (2011) [22] demonstrated that a small percentage of adolescents had low concentrations of the same series of immunological cells, while investigating the reliability and impact of a social support system on adolescent health, whilst the vast majority presented values above of that considered ideal for the immunity of HIV+ people.

Even through psychological and biological changes, the social is somewhat shaken when one takes into account the family of adolescents. Of course, they seek to separate themselves from their families in order to reaffirm their identity and their belonging to a group other than their own family [29]. As mentioned earlier, there is a conflict of independence and family dependency; however, it is of utmost importance the maintenance of family dependency at a certain level, taking into account that adolescents living with HIVIAIDS need material and affective support, to help cope with the condition. Even with all the and free of charge, necessary pharmaceutical and health apparatus available in the current health model [30], it is the parental responsibility to materially support the children, mainly generating subsidies and strategies for the continuity of this care in health facilities. In addition and most relevant of all, the affective apparatus to continue performing the proper treatment.

\section{Conclusion}

The present study reached the objective proposed from the sample results of scientific works developed around the world regarding the importance of social support in the life of adolescents living with a current and stigmatizing chronic disease.

The research brought important and reflective data in the national and international scenario regarding the subject of study. The literature review highlights the importance of social support to adolescents living with HIVIAIDS, since this public is in a situation of greater vulnerability due to age, because it is a phase of discoveries, mainly related to their sexuality. In addition, there may be the risk of negative feelings due to the existing social prejudice and stigma towards HIV. In this perspective, it is highlighted as extremely relevant familial and extrafamilial support, especially regarding to health services and non-governmental organizations in coping with the disease, adoption of safer sexual practices and treatment, thus providing a new perspective and a better quality of life for these individuals.

In addition, it is relevant to conduct studies that deepen the analysis of social support to adolescents living with HIV/AIDS, since such support offered by both family members and institutions are considered an optimizing factor regarding physical, social and psychological health, in positive behaviors and in coping with the condition of living with HIV and AIDS.

\section{References}

1. Joint United Nations Programme on HIVIAIDS (UNAIDS). Global report: UNAIDS report on the global AIDS epidemic 2013. Geneva; 2013.

2. Joint United Nations Programme on HIVIAIDS (UNAIDS). Global AIDS UP DATE 2016. Geneva; 2016.

3. Ministério da Saúde (BR), Secretaria de Vigilância em Saúde, Departamento de DST, AIDS e Hepatites Virais. Boletim Epidemiológico AIDS e DST. 2016. 
4. Ministério da Saúde (BR), Secretaria de Vigilância em Saúde, Departamento de DST, AIDS e Hepatites Virais. Protocolo clínico e diretrizes terapêuticas para manejo da infecção pelo HIV em crianças e adolescentes. 2014.

5. Galano E, Turato ER, Delmas P, Coté , Gouvea AFTB, Succi RCM et al. Vivências dos adolescentes soropositivos para HIV/ Aids: estudo qualitativo. Rev. paul. pediatr. [online]. 2016, vol.34, n.2 [cited 2017-01-17], pp.171-177. Available from: http://www.scielo.br/scielo.php?script=sci arttext\&pid=S010305822016000200171\&lng=en\&nrm=iso.

6. Borges JMC, Pinto JA, Ricas, J. Crianças e adolescentes vivendo com HIV/aids: "que doença é essa?". Reverso [online]. 2015, vol.37, n.70 [cited 2017-01-17], pp. 67-73 . Disponível em: http:// pepsic.bvsalud.org/scielo.php?script=sci arttext\&pid=S010273952015000200009\&lng=pt\&nrm=iso.

7. Sehnem GD, Favero NB, Bonadiman POB. Adolescentes que vivem com HIV/Aids: as redes de apoio social. Rev Enferm UFSM 2015;5(2): 349-359

8. Bortolotti LR, Spindola T, Taquette SR, Fonte VRF, Pinheiro COP, Francisco MTR. The Meaning of Living with HIV/aids in Adolescence: a Descriptive Study . Online Braz J Nurs [internet] 2014 Sep [cited 2017-01-17]; 13(4):537-48.

9. Bryson Y. Cuidar dos cuidadores para aumentar a aderência anti-retroviral em crianças e adolescentes infectados pelo HIV. J Pediatr (Rio J). 2014; 90: 533-5.

10. Mendes K, Silveira R, Galvão C. Revisão integrativa: método de pesquisa para a incorporação de evidências na saúde e na enfermagem. Texto contexto - enferm. 2008;17(4).

11. Ganong LH. Integrative reviews of nursing research. Res. Nurs. Health. 1987; 10(1):1-11

12. Ursi ES, Gavão CM. Prevenção de Lesões de Pele no Perioperatório: revisão integrativa da literatura. Rev. Latino-Am. Enferm. 2006; 14(1):124-31

13. Stetler CB, Morsi D, Rucki S, Broughton S, Corrigan B, Fitzgerald $J$, et al. Utilization-focused integrative reviews in a nursing service. Appl. Nurs. Res. 1998;11(4):195-206.

14. Sehnem, GD, Favero, NB, Bonadiman, POB. Adolescentes que vivem com HIVIAIDS: As redes de apoio social. Rev. De Enfermagem da UFSM. 2016; 5(2): 349-359.

15. Owe GA, Gibson RC, Christie CDC. Infecção pelo HIV, abuso sexual e apoio social em adolescentes jamaicanos referidos a um serviço psiquiátrico. West Indian med. J. 2008; 57(3):307-11.

16. Lee S, Yamazaki M, Harris D, Harper G, Ellen J. Social Support and Human Immunodeficiency Virus-Status Disclosure to Friends and Family: Implications for Human Immunodeficiency VirusPositive Youth. Journal of Adolescent Health. 2015;57(1):73-80.

17. Peu M. Health promotion strategies for families with adolescents orphaned by HIV and AIDS. Int Nurs Rev. 2014;61(2):228-36

18. Qiao S, Li X, Stanton B. Social Support and HIV-related Risk Behaviors: A Systematic Review of the Global Literature. AIDS Behav. 2013;18(2):419-41.

19. Mavhu W, Berwick J, Chirawu P, Makamba M, Copas A, Dirawo J et al. Enhancing Psychosocial Support for HIV Positive Adolescents in Harare, Zimbabwe. PLoS ONE. 2013;8(7):e70254.
20. Salama C, Morris M, Armistead L, Koenig L, Demas P, Ferdon C et al. Depressive and conduct disorder symptoms in youth living with HIV: The independent and interactive roles of coping and neuropsychological functioning. AIDS Care. 2013;25(2):160-68.

21. Tucker J, Hu J, Golinelli D, Kennedy D, Green H, Wenzel S. Social Network and Individual Correlates of Sexual Risk Behavior Among Homeless Young Men Who Have Sex With Men. Journal of Adolescent Health. 2012;51(4):386-392.

22. Hosek S, Lemos D, Harper G, Telander K. Evaluating the Acceptability and Feasibility of Project ACCEPT: An Intervention for Youth Newly Diagnosed with HIV. AIDS Education and Prevention. 2011;23(2):128-144.

23. Di Risio M, Ballantyne P, Read S, Bendayan R. "HIV isn't me...": HIV+ adolescents' experiences in a positive context of support and treatment. AIDS Care. 2011;23(6):694-699.

24. Doku P, Dotse J, Mensah K. Perceived social support disparities among children affected by HIV/Aids in Ghana: a cross-sectional survey. BMC Public Health. 2015;15(1).

25. Camlin C, Snow R. Parental Investment, Club Membership, and Youth Sexual Risk Behavior in Cape Town. Health Education \& Behavior. 2008;35(4):522-540.

26. Greifinger R, Dick B. Provision of psychosocial support for young people living with HIV: voices from the field. SAHARA-J: Journal of Social Aspects of HIV/Aids. 2011;8(1):33-41.

27. Swartz S, Deutsch C, Makoae M, Michel B, Harding J, Garzouzie $G$ et al. Measuring change in vulnerable adolescents: Findings from a peer education evaluation in South Africa. SAHARA-J: Journal of Social Aspects of HIV/Aids. 2012;9(4):242-54.

28. Cruz, TJ. Adolescente, família e o profissional de saúde. Adolescência e Saúde [Internet]. 2007 [cited 31 March 2016]; 4(3):45-50. Available from: http://www.adolescenciaesaude. com/detalhe artigo.asp?id=100

29. Aberastury A, Knobel M. La Adolescencia normal. Buenos Aires: Editorial Paidós; 1971.

30. Ministério da Saúde (Brasil). Quais são os antirretrovirais | Departamento de DST, Aids e Hepatites Virais [Internet]. Aids. gov.br. 2016 [cited 31 March 2016]. Available from: http://www. Aids.gov.br/pagina/quais-sao-os-antirretrovirais.

\section{Publish in International Archives of Medicine}

International Archives of Medicine is an open access journal publishing articles encompassing all aspects of medical science and clinical practice. IAM is considered a megajournal with independent sections on all areas of medicine. IAM is a really international journal with authors and board members from all around the world. 